\title{
Dynamics of Batumi Anticyclone from the Satellite Measurements
}

\author{
A.A. Kubryakov, S.V. Stanichny \\ Marine Hydrophysical Institute, Russian Academy of Sciences, Sevastopol, \\ Russian Federation \\ e-mail: arskubr@ya.ru
}

\begin{abstract}
Eddy dynamics in the south-eastern part of the Black Sea is studied on the basis of satellite altimetry data and optical and infrared satellite imagery. Mesoscale variability using the recently developed methods of eddy automatic identification from a known altimetry-derived velocity fieldis investigated. The anticyclonic eddies in the basin intensifies in summer, and weakens in winter. Average radius of the long-lived anticyclones vary from $40-45 \mathrm{~km}$ in winter to $\sim 60 \mathrm{~km}$ in summer-autumn season. In winter cyclonic eddies develop, particularly, a strong mesoscale cyclonic eddy is generated in the Batumi anticyclone area. It originates presumably from intense local cyclonic wind vorticity arising in this zone in winter. It is shown that, in most cases, Batumi anticyclone is not stationary. Having been formed in the coastal southeastern part of the Black Sea, it moves to the northwest at a speed $1-5 \mathrm{~cm} / \mathrm{s}$ reaching sometimes the basin northeastern part. Over 20-years period 8 anticyclones with lifetime exceeding 10 months were observed in two cases it exceeds one year. The Batumi anticyclone strongly impacts on the biooptical characteristics in the basin. During his lifetime it can capture the turbid coastal waters in his core for several times, which increase its reflectancecompare to surrounding waters. On the other hand, downwelling motions in the eddy can lead to the lowering of the reflectance(for example, during the coccolithophorids blooming).
\end{abstract}

Keywords: eddy dynamics, synoptic eddies, satellite data, the Black Sea.

DOI: 10.22449/1573-160X-2015-2-59-68

(C) 2015, A.A. Kubryakov, S.V. Stanichny

(C) 2015, Physical Oceanography

Introduction. Quasi-stationary Batumi anticyclone situated in the southeastern part of the basin, is one of the most intense eddy formations observed in the Black Sea. Research of the last decades showed Batumi anticyclone to be nonstationary in the full sense of the word and to have the pronounced seasonal variability. Its formation and development starts in spring after the Rim Current (RC) weakening, the intensification - in summer and its breaking - in autumn [1, 2]. Mesoscale dynamics in the south-east of the Black Sea can have rather complicated nature during the year: a great quantity of quite intense eddies of different signs are often observed here [3-6]. Nevertheless Batumi anticyclone is considered to be one of the largest mesoscale formations in the basin. The researchers show it to form and break in the south-east of the Black Sea. It doesn't move along the basin, as opposed to eddies, formed in the other areas of the sea, that in their majority move in the cyclonic direction along the coast at a speed $\sim 1-15 \mathrm{~cm} / \mathrm{s}$ and significantly remote from their point of formation [3-6].

The works, dedicated to the research of Batumi anticyclone dynamics, are mainly based on the data of hydrological surveys $[1,5,7]$ and satellite measurements in optical and infrared ranges [3-6]. Having a number of advantages, these techniques, however, don't permit to obtain long continuous observations of eddy dynamics, as the possibility of performing continuous scientific ship expeditions is limited and the cloudiness often impedes obtaining satellite data.

In the resent work to study eddy dynamics of the south-eastern Black Sea the array of geostrophic velocities of 1993 - 2013 period, reconstructed from the measurements combined satellite altimeters, is used. Mesoscale variability is studied on 
the basis of an automated eddy-identification method from the known altimetryderived velocity field. Application of these methods allows to identify automatically all sufficiently large mesoscale eddies and track their evolution and movement. On the base of such approach the seasonal variability of the characteristics of different sign eddies have been studied. Analysis of optical and infrared satellite images, along with altimetry data allowed show robustly that, in most cases, Batumi anticyclone was not stationary. Having been formed in the coastal southeastern part of the Black Sea, it moves to the northwest at a speed $1-5 \mathrm{~cm} / \mathrm{s}$ achieving sometimes the basin northeastern part. At that the lifetime of such an eddy can amount a year. In winter a strong mesoscale cyclonic eddy is generated in the Batumi anticyclone area. It originates presumably from intense local cyclonic wind vorticity arising in this zone that is well-seen from the MM5 regional atmospheric model with high spatial resolution.

Data and methods. The study is based on the array of surface geostrophic velocities obtained from satellite altimetry data. Combined measurements of the several satellites the mapped level anomalies on the regular grid are determined. AVISO (http://www.aviso.oceanobs.com/) regional delayed time dataset with 7 day time resolution and $1 / 8^{\circ}$ spatial resolution within the $1993-2013$ period, is used. Anomalies of geostrophic currents velocities are calculated from the geostrophic balance equation from the sea level anomalies. For automatic eddy identification the winding angle method is applied. It is based on selection of the areas limited by closed streamlines $[8,9]$. For eddies moving in the stream the streamlines could be not closed, so in the present task the fields of geostrophic current velocity anomalies were used.

For eddy identification in the stationary velocity field, corresponding to one momentum of time, in each grid node the virtual particle is released, which trajectory is calculated using the Euler numerical scheme, as follows:

$$
r(x, y, t+d t)=r(x, y, t)+v^{\prime}(x, y) d t,
$$

where $r$ is the radius vector of the particle; $v^{\prime}(x, y)$ is the time stationary field for the fixed date; $d t$ is the time step. Further at the each step the particle velocity deviation sum angle from the initial position is calculated. Exceeding $360^{\circ}$ sum angle the particle performs a circular turn, i.e. is situated in the closed streamline. Consequently, the corresponding grid node is in the eddy. Clusters of the marked grid nodes are the individual eddies.

After marking the eddies on all the velocity maps, trajectories of the individual eddies are determined. For this purpose the distance between centers of the eddies on two consequent maps is calculated and single sign eddy pairs are defined. Maximum eddy displacement should not exceed $100 \mathrm{~km}$ per 7 days, that corresponds to $15 \mathrm{~cm} / \mathrm{s}$ velocity limit under the existing evaluations $[1,3,10]$. As the altimetry data quality is worse near the coast, where there is a large amount of eddies in the Black Sea, the method has been modified for the coastal area. It was considered that the virtual particle is situated in the eddy, if the trajectory start and end are in the coastal grid node and the total winding angle exceeds $270^{\circ}$. See detailed description of the used method in [11]. Altimetry data resolution does not allow identifying eddies with less than $20 \mathrm{~km}$ radius that is why only large formations will be taken into account during the analysis.

For the method validation a position of eddies, identified in the velocity field under satellite altimetry data, was compared with their manifestation in the fields of other satellite parameters. As it will be demonstrated below, the suggested method permits to identify eddy formations quite accurately. During the analysis we 
considered the data of Moderate-resolution Imaging Spectroradiometer (MODIS) on the sea surface temperature, chlorophyll-a concentration and remote sensing reflectance at $555 \mathrm{~nm}$ with $1 \mathrm{~km}$ spatial resolution (Level 2). The data were obtained in the Remote Sensing Department of Marine Hydrophysical Institute (http://dvs.net.ua).

Eddy dynamics in the south-eastern part of the basin. In the present work the south-eastern part of the Black Sea, limited by the coordinates $40-43,5{ }^{\circ} \mathrm{N}$, $37-42^{\circ} \mathrm{E}$, is studied. This area is known to have complex mesoscale dynamics. A great quantity of both small and large [3] different sign eddies are often observed here. For example, Fig. 1 shows the scheme of surface temperature (SST) for December, 31, 2012, where a large anticyclone and two large cyclones with $100 \mathrm{~km}$ are marked. Ellipses show the opposition of the eddies, identified from satellite altimetry data. The position of eddies in the passive tracer fields match the eddies, identified using automated eddy-identification method.

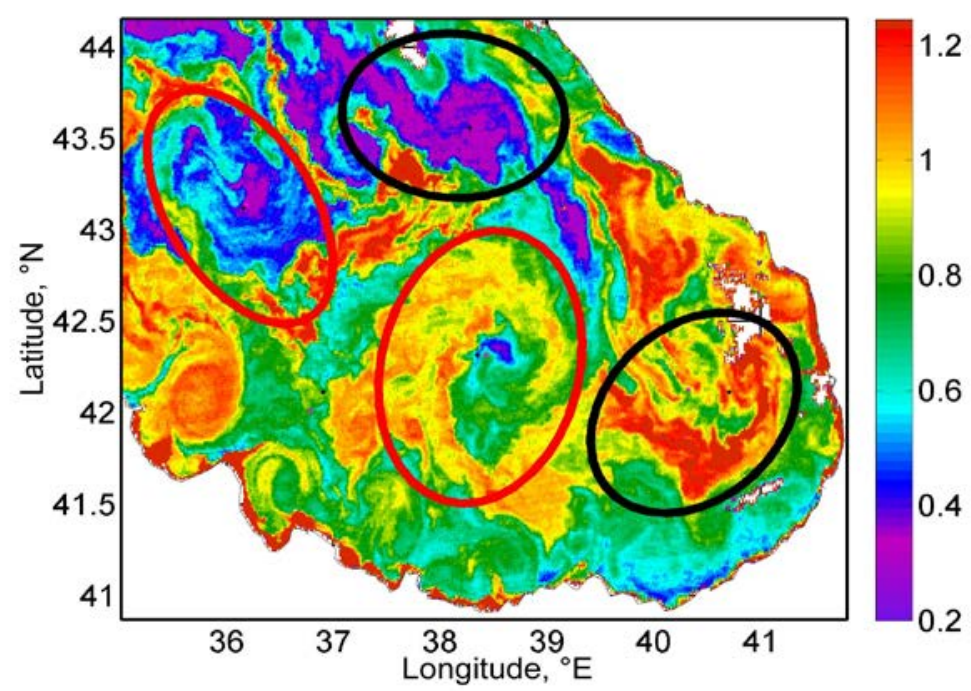

Fig. 1. Remote sensing reflectance $\left(\mathrm{mW} /\left(\mathrm{mkm} \cdot \mathrm{ster} \cdot \mathrm{cm}^{2}\right)\right)$ at $555 \mathrm{~nm}$ for Dec, 31, 2012. Ellipses contour the eddies identified from satellite altimetry data (cyclones are marked by black color, anticyclones - by red one)

Automated eddy-identification method allows determining of the temporary variability of the quantity of eddies and their various characteristics. Fig. 2, a shows seasonal variability of quantity of the long-living (with lifetime over 3 months) cyclones and anticyclones in the researched area. As one can see, anticyclonic eddies prevail in summer and cyclonic ones - in winter.

In June - August about two long-living anticyclones (on the average for 20 years 1.8 per month) and a cyclone simultaneously exist, in December - February about two cyclones (1.7) and an anticyclone. Anticyclonic activity starts to develop in March - April, when the RC weakens [12, 13]. Radius of the long-living anticyclones at the initial stage of their development in this season is $40-45 \mathrm{~km}$ average (Fig. 2, b). Their maximum quantity is observed in May - July, at the same time they reach the maximum size (radius $\sim 60 \mathrm{~km}$ ) in September - October. Lifetime of such anticyclones can exceed a year, but on an average it is $4-5$ months.

PHYSICAL OCEANOGRAPHY NO. 2 (2015) 

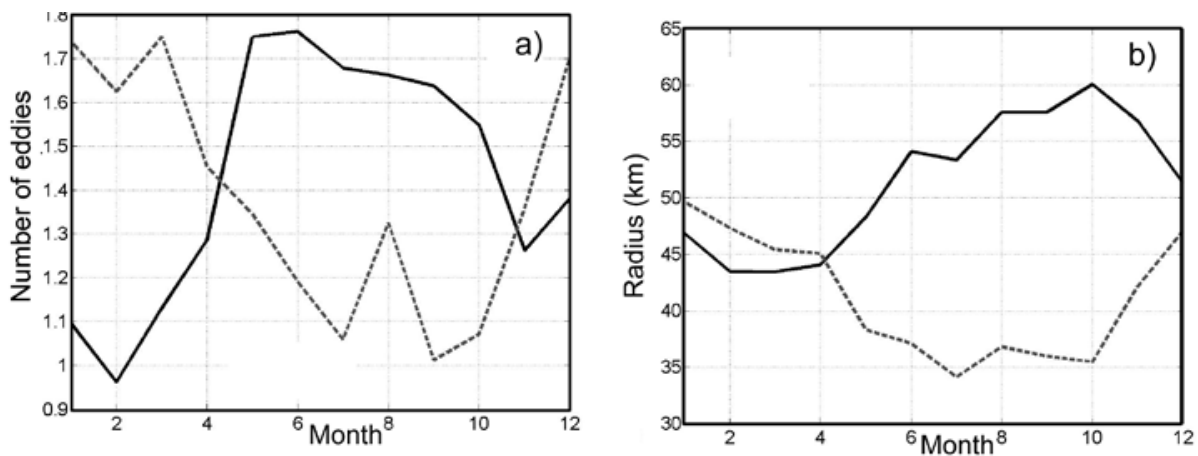

Fig. 2. Seasonal variability of the quantity $(a)$ and radius $(b)$ of the observed anticyclones (solid line) and cyclones (dashed line) with lifetime over 3 months in the south-eastern part of the Black Sea

In the end of autumn - the beginning of winter anticyclones attenuate and large mesoscale cyclones develop in this area (see them in Fig. 1). This result was obtained earlier in the [14]. Such cyclones are constantly monitored every year. The largest ones form in the extreme south-eastern part of the basin to the right of anticyclones, which are situated to the west. Radius of the cyclones in winter months is $50 \mathrm{~km}$ on average, in summer $-35 \mathrm{~km}$. Cyclonic activity is quite intense from November to April.

Appearance of such large cyclones probably relates to the direct local wind curl impact. Calculations of the MM5 atmosphere model with high spatial resolution demonstrate that the most intense wind cyclonic curl cell is observed from November to April in this area (Fig. 3) [15]. Cyclonic curl is formed due to the impact of the along-shore winds with monsoon nature in winter period [16]. Direction change of the coastal line in this area leads to the sharp shift of wind direction and, consequently, to appearance of the local intense wind cyclonic vorticity area.

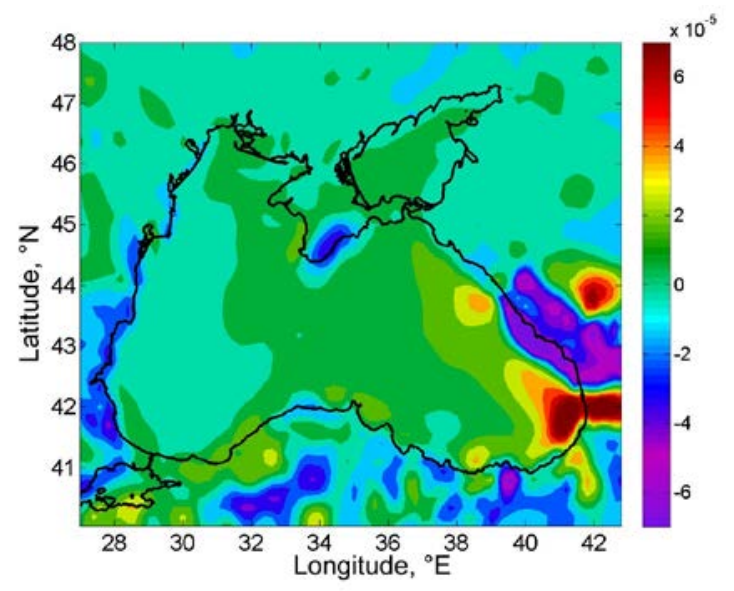

Fig. 3. Wind curl $\left(\mathrm{s}^{-1}\right)$ from the $M M 5$ model, averaged for December 2000 - 2010

Batumi anticyclone dynamics. Batumi anticyclone is one of the largest mesoscale formations in the Black Sea. It is considered Batumi one, as it has formed 
and exists in the south-eastern part for a long period of time. Fig. 4 shows trajectories of all the eddies developed in 1993 - 2013 period with lifetime over 40 weeks, i. e. over 10 months. The trajectories were obtained by eddy-automated identification method according from satellite altimetry data.

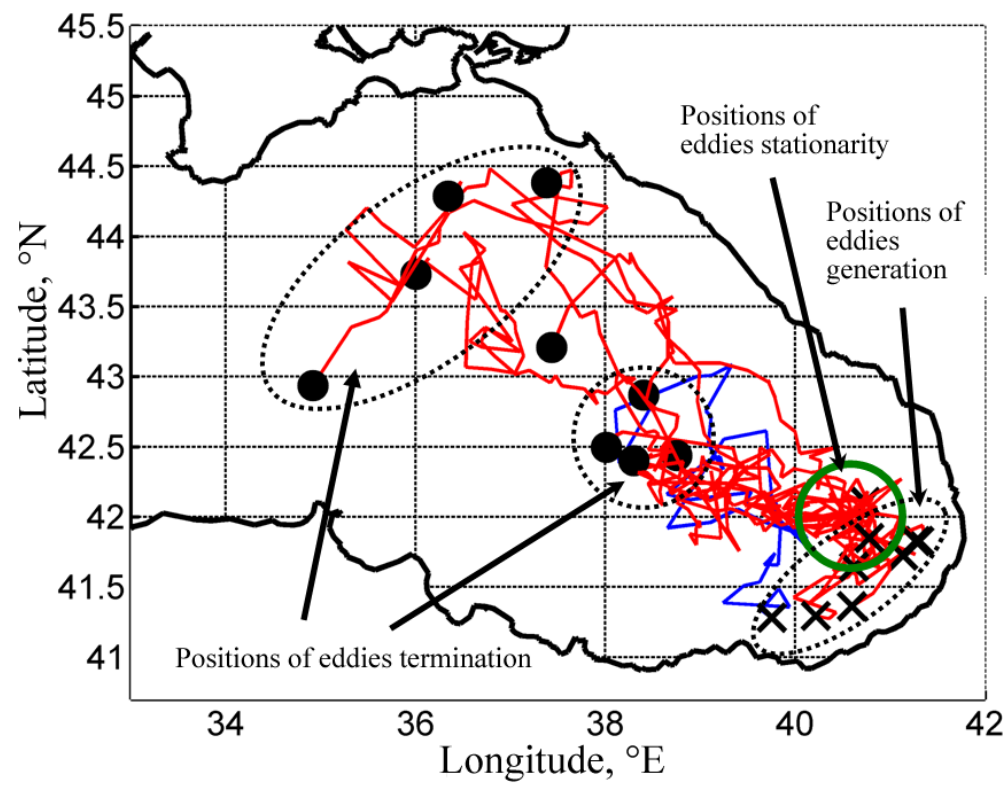

Fig. 4. Trajectories of the long-living (over 10 months) anticyclones (red line) and cyclones (blue line), identified from altimetry data for 1993 - 2013 period. Crosses mark the place of eddy formation, rounds - the places of their disappearance

There were 8 anticyclones and a 1 cyclone with such features observed within the mentioned period. The majority of eddies was formed in the coastal southeastern part of the basin (crosses). However, none of them remained stationary during its whole existence period. All the anticyclones shifted to the north-west, some of them - up to $42.5^{\circ} \mathrm{N} 38-39^{\circ} \mathrm{E}$ area, the others moved further, almost up to the Crimean coast $\left(44^{\circ} \mathrm{N} 35-37^{\circ} \mathrm{E}\right)$. Translation velocity of the anticyclones is $1-$ $5 \mathrm{~cm} / \mathrm{s}$. Minimum translation velocities $0-2 \mathrm{~cm} / \mathrm{s}$ are observed in the stationarity zone in the area of $42^{\circ} \mathrm{N} 40.5^{\circ} \mathrm{E}$ (Fig. 4). Here anticyclones slow their movement and remain quasi-stationary for quite a long time period.

For a more detailed analysis lets consider two examples of evolution of the individual eddies on the base of satellite optical, infrared and altimetry data.

Trajectory of Batumi anticyclone formed in the late February 2008 is demonstrated on Fig. 5, $a$. On the map of remote sensing reflectance at $555 \mathrm{~nm}$ (RRS_555) for April, 3, 2008 (Fig. 6, $a$ ) we can see the studied anticyclone to be an intense coastal eddy in its initial stage, appeared as a result of the RC instability. It is centered in the point with $41.7^{\circ} \mathrm{N} 40.5^{\circ} \mathrm{E}$ coordinates. We should note quite a good match of the eddy position area, obtained by auto-identification method from altimetry data (the ellipses on Fig. 6) and its manifestation in the reflectance. In the moment of formation this eddy is characterized by high values of RRS_555, as it contains a large amount of the turbid coastal waters. By July, 9, 2008 it significant- 
ly grows in size, occupying practically the whole south-eastern part of the basin (Fig. 6, b). Besides, unlike the first image, the anticyclone is featured by the lowered values of RRS_555 as compared with the ambient waters containing a large quantity of coccolithophores. By July, 24, 2008 its center shifts considerably to the north-west in the point with $42.1^{\circ} \mathrm{N} 40.1^{\circ} \mathrm{E}$ coordinates (Fig. 6, $c$ ). The anticyclone pulls into a large amount of water with high values of RRS_555, concentrated in its center. By September, 12, 2008 the eddy shifts to the west (having center in the point with $42.2^{\circ} \mathrm{N} 39.4^{\circ} \mathrm{E}$ coordinates) and possesses lowered values of $R R S \_555$ (Fig. 6, d). By October, 18, 2008 the anticyclone again pulls into an abundance of turbid waters and becomes more visible in the field of RRS_555 (Fig. 6, e). At this time the formed "winter" cyclone starts to be noticeable in the RRS_555 to the east. The pattern shown on Fig. 6, e, with the eddy couple cyclone - anticyclone with the cyclone on the east, is monitored almost every year in the late autumn - early winter.
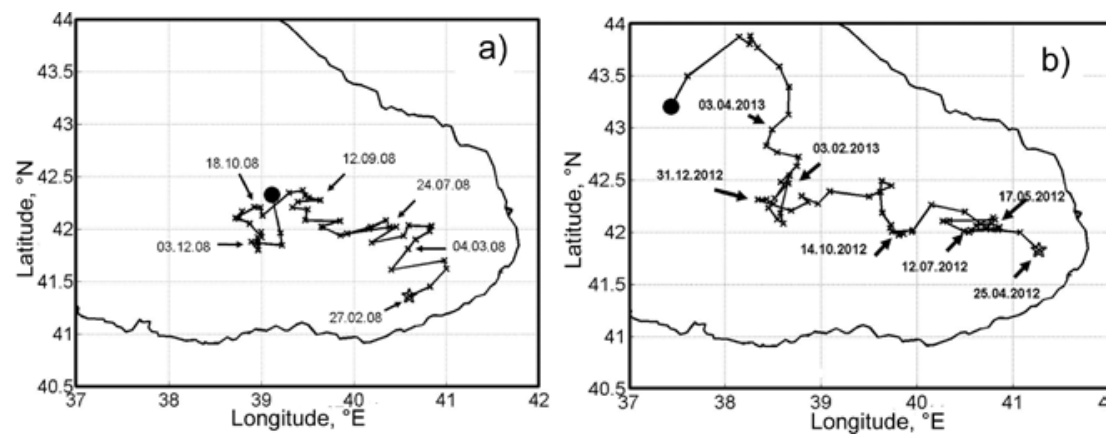

Fig. 5. Trajectories of Batumi anticyclone (stars are the places of formation, rounds are the places of dissipation)

According to optical data, last time the anticyclone is seen on December, 3, 2008 (Fig. 6, d). Its size is similar to the adjacent "winter" cyclone (radius $\sim 50 \mathrm{~km}$ ). Cloudiness prevents to observe the further evolution of the anticyclone. Under altimetry data, it existed up to the mid-January, 2009, i.e. its life time was about 11 months. At this time period Batumi anticyclone shifted to the north-west to the distance about $200 \mathrm{~km}$. It should also be noted that the values of remote sensing reflectance in the anticyclone were several times higher and several times lower than in the environment. Such variability is, firstly, related with the capturing of turbid waters by the eddy. At the eddy lifetime period such event occurred several times.

The second example of Batumi anticyclone evolution is shown on Fig. 5, b. By the moment of the formation in the early April 2012 in the $41.7^{\circ} \mathrm{N} 41^{\circ} \mathrm{E}$ area it looked like a small coastal eddy with $30 \mathrm{~km}$ radius. By May 2012 the eddy shifts to the north-west and reaches large size gaining $50 \mathrm{~km}$ radius (Fig. 7, a). Its center is well-marked in the RRS_555, as it features by lowered brightness values compared with the periphery waters containing a large quantity of coccolithophores. This pattern with the low brightness values in the center and the high ones - in the periphery remains till July, 12, 2012 (Fig. 7, b), when waters of the eddy becomes more homogeneous. From early May to early August the eddy is practically stationary, rotating round the point with $42{ }^{\circ} \mathrm{N} 40.5^{\circ} \mathrm{E}$ coordinates. In mid-August the 
anticyclone starts shifting quite quickly to the west. By October, 14, 2012 the eddy, marked in the surface temperature field (Fig. 7, c), moves to the west till $39 .{ }^{\circ} \mathrm{E}$. Its radius grows up to $90 \mathrm{~km}$.
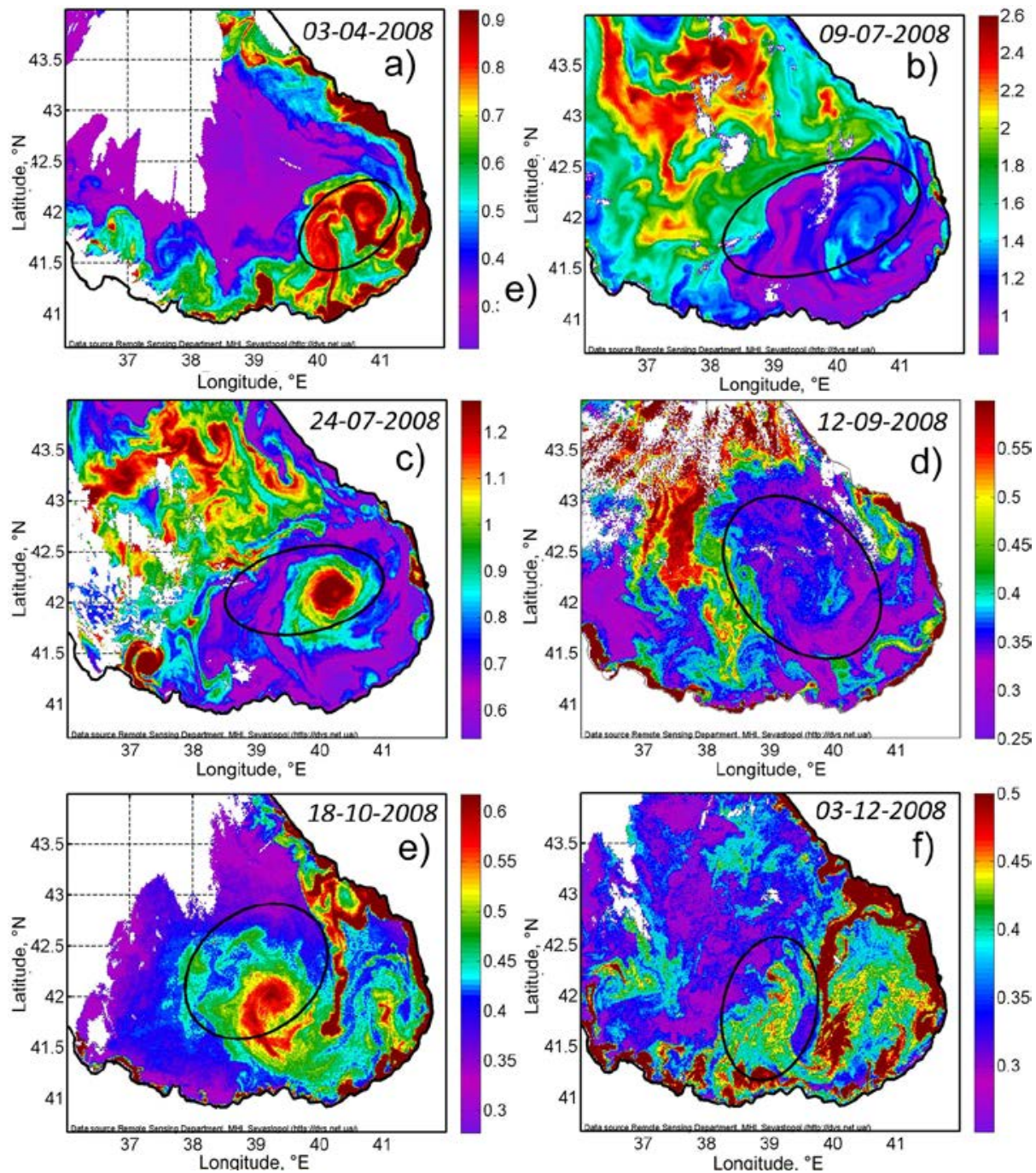

Fig. 6. Upwelling radiation brightness scheme $\left(\mathrm{mW} /\left(\mathrm{mkm} \cdot \mathrm{ster} \cdot \mathrm{cm}^{2}\right)\right)$ at $555 \mathrm{~nm}$ wave length for Apr, 3, 2008 - a, Jul, 9, 2008 - b, Jul, 24, 2008 - c, Sept, 12, 2008 - d, Oct, 18, 2008 - e, Dec, 3, 2008 - $f$. Ellipses contour the eddies identified under satellite altimetry data

In the early November 2012 a powerful cyclone forms to the east of the anticyclone. This eddy couple is well-noticeable in the surface temperature field for December, 31, 2012 (Fig. 7, d). At the same time the anticyclone shifts more westward till $38.5^{\circ} \mathrm{E}$. Dynamic structure in December 2012 is almost identical to the one in the first example in December, 2008. Approximately in a year after the formation, on March, 2, 2013 the studied anticyclone centered in $42.5^{\circ} \mathrm{N} 38.5^{\circ} \mathrm{E}$ is accurately visible in the brightness scheme (Fig. $7, e$ ). Then it starts moving fast to 
the north and considerably reduces in size. Later on April, 3, 2014, the eddy center is situated at $43^{\circ} \mathrm{N} 39^{\circ} \mathrm{E}$ (Fig. 7, f), its radius is $40 \mathrm{~km}$. After the studied eddy merges with the powerful anticyclone near the Caucasian coast that doesn't permit reliable monitoring of its further moving pattern. Thus, the studied anticyclone had existed for more than a year and shifted from its place of formation to the northwest for over $250 \mathrm{~km}$.
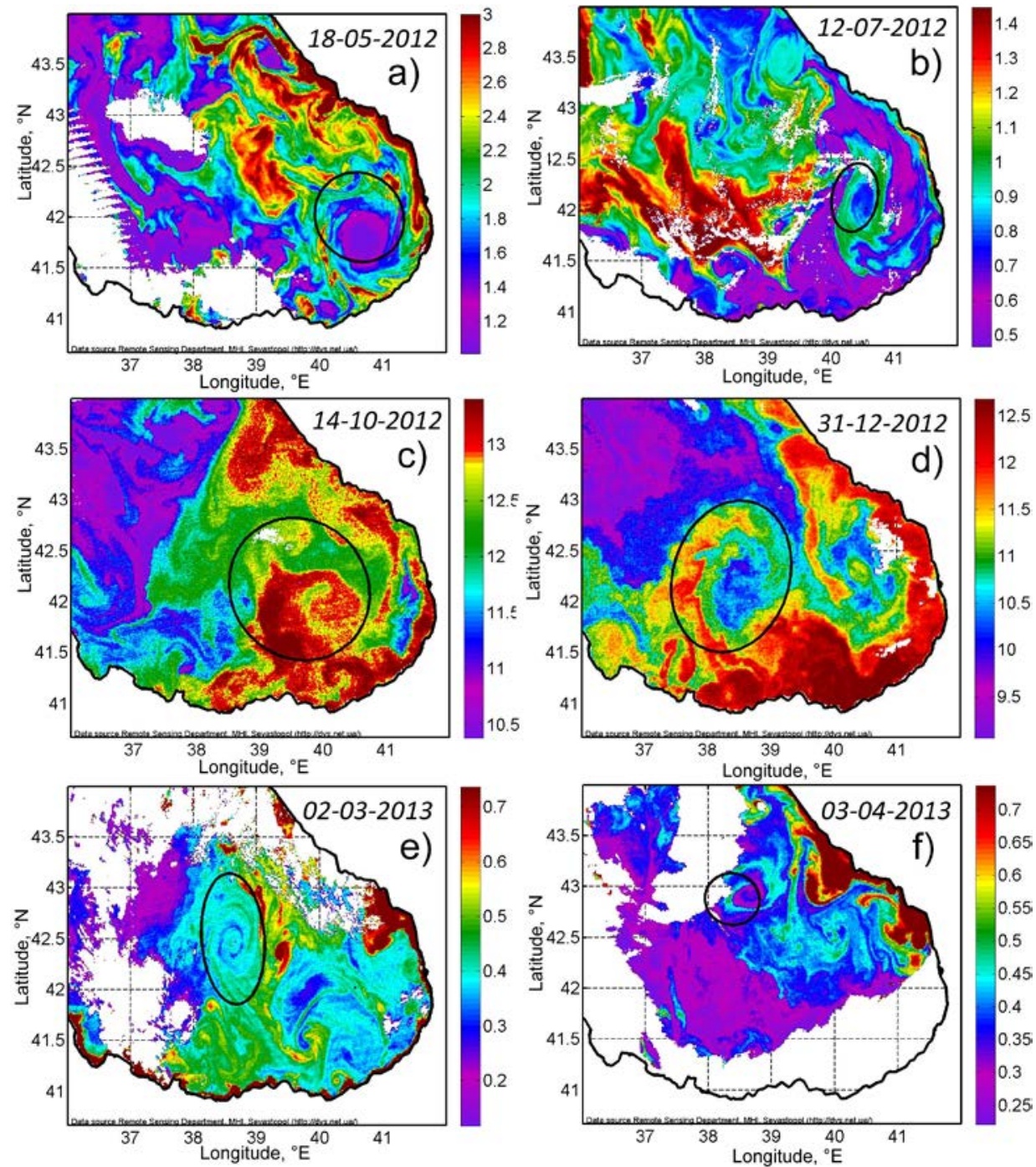

Fig. 7. Upwelling radiation brightness scheme $\left(\mathrm{mW} /\left(\mathrm{mkm} \cdot \mathrm{ster} \cdot \mathrm{cm}^{2}\right)\right)$ at $555 \mathrm{~nm}$ wave length $(a, b, c$, $d)$ and sea surficial temperature $\left({ }^{\circ} \mathrm{C}\right)(e, f)$ for May, 18, $2012-a$, Jul, 12, $2012-b$, Oct, 14, $2012-c$, Dec, 31, $2012-d$, March, 2, $2013-e$, Apr, 3, $2013-f$. Ellipses contour the eddies identified under satellite altimetry data

Conclusion. In the present article on the basis of eddy-automated identification from the known velocity field, obtained according to satellite altimetry data, the eddy dynamics in the south-eastern part of the Black Sea was researched. Ap- 
plication of the aforementioned method including analysis of the satellite optical and infrared imaged allowed obtaining the following conclusions.

1. It is demonstrated that in this area in summer period anticyclonic eddies prevail and in winter one - the cyclonic eddies. The intense cyclones are formed here almost every winter, they are well-expressed in the field of the optical and temperature tracers. Such cyclones are situated in the eastern part of this area of the Black Sea. They are often observed along with the powerful anticyclone situated westward. Possible cause of formation of these cyclones is the intense cyclonic wind circulation cell, appearing here in winter period and well-marked under the MM5 regional atmospheric model calculations. Appearance of this cell is probably due to the intense alongshore winds of monsoon nature and coastline curvature.

2. Batumi anticyclone develops from the intense coastal eddy, appearing in April - May, probably due to the instability of large-scale currents. It grows fast in size and shifts to the northwest in the center of the south-eastern area. There in summer period the anticyclone becomes quasi-stationary, and then begins to move further to the north-west, sometimes reaching the north-eastern part of the basin. This movement can be reliably traced via satellite images and satellite altimetry data. In our opinion, the main reason for the displacement of the eddy to the west is west direction of propagation of the Rossby waves. It is known that in the ocean eddies formed due to the instability of the eastern boundary currents, typical behavior is to move to the west with the phase velocity of the Rossby waves [17]. Perhaps the more reason for this shift can be the intense cyclone formation in the winter period. At the same time the shift of Batumi anticyclone to the north is most likely due to the involvement of the eddy in the general cyclonic circulation of water in the basin.

3. The time existence of Batumi anticyclone can exceed one year.

Satellite altimetry data allow performing long-term monitoring of mesoscale eddies, and now they are an important source of new information about the dynamics of mesoscale ocean.

Acknowledgements. Auto-identification of eddies and altimetry data analysis were carried out under the support of the Ministry of Education of the Russian Federation, Contract No. 14.604.21.0044. Satellite optical information analysis is performed with support from RFBR Grant No. 14-45-01526.

\section{REFERENCES}

1. Ivanov, V.A., Belokopytov, V.N., 2013, “Oceanography of the Black Sea”, Sevastopol, MGI NAN Ukrainy, ECOSY-Gidrofizika, 210 p.

2. Korotaev, G., Oguz, T. \& Nikiforov, A. [et al.], 2003, "Seasonal, interannual, and mesoscale variability of the Black Sea upper layer circulation derived from altimeter data”, J. Geophys. Res., vol. 108, no. C4, 3122, doi: 10.1029/2002JC001508.

3. Ginzburg, A.I., Kostianoy, A.G., Soloviev, S.V. \& Stanichny, S.V., 2000, "Izmenchivost' vikhrevoy kartiny v yugo-vostochnoy chasti Chernogo morya [Evolution of eddies and jets in the northeastern Black Sea in autumn 1997]”, Issledovanie Zemli iz kosmosa, no. 1, pp. 3-14 (in Russian).

4. Ginzburg, A.I., Zatsepin, A.G. \& Kremenetskii, V.V. [et al.], 2008, "Mezomasshtabnaya dinamika vod Chernogo morya [Mesoscale dynamics of the Black Sea waters]”, Okeanologiya na starte 21 veka, Moscow, Nauka, pp. 11-42 (in Russian).

PHYSICAL OCEANOGRAPHY NO. 2 (2015) 
5. Zatsepin, A.G., Ginzburg, A.I. \& Kostianoy, A.G. [et al.], 2003, “Observations of Black Sea mesoscale eddies and associated horizontal mixing”, J. Geophys. Res., vol. 108, no. C8, doi: 10.1029/2002JC001390.

6. Ginzburg, A.I., Kostianoy A.G., \& Soloviev, D.M. [et al.], 2000, "Remotely sensed coastal/deep-basin water exchange processes in the Black Sea surface layer", Elsevier Oceanogr. Ser., no. 63, pp. 273-287.

7. Golubev, Yu.N., Tuzhilkin, V.S., 1990, "Kinematika i struktura vod antitsiklonicheskogo vikhrevogo obrazovaniya $v$ tsentral'noy chasti Chernogo morya [Kinematics and structure of the anticyclonic eddy waters in the central part of the Black Sea]”, Okeanologiya, vol. 30, no. 4, pp. 575-581 (in Russian).

8. Chaigneau, A., Gizolme, A. \& Grados, C., 2008, "Mesoscale eddies off Peru in altimeter records: Identification algorithms and eddy spatio-temporal patterns”, Progr. Oceanogr., vol. 79, no. 2, pp. 106-119.

9. $\quad$ Ari Sadarjoen, I., Post, F.H., 2000, "Detection, quantification, and tracking of vortices using streamline geometry”, Comp. and Graph., vol. 24, no. 3, pp. 333-341.

10. Latun, V.C., 1989, "Antitsiklonicheskie vikhri v Chernom more letom 1984 g. [Anticyclonic eddies in the Black Sea in summer 1984]", Morskoy gidrofizicheskiy zhurnal, no. 3, pp. 27-35 (in Russian).

11. Kubryakov, A.A., Stanichnyi, S.V., 2015, "Mesoscale eddies in the Black Sea from satellite altimetry data”, Okeanology, vol. 55, no. 1, pp. 1-13.

12. Zatsepin, A.G., Ginzburg, A.I. \& Evdoshenko, M.A., 2002, "Vikhrevye struktury i gorizontal'nyy vodoobmen $v$ Chernom more [Eddies and horizontal water exchange in the Black Sea", Complex research of the north-eastern Black Sea]”, Moscow, Nauka, pp. 55-81 (in Russian).

13. Kubryakov, A.A., Stanichnyi, S.V., 2015, "Seasonal and interannual variability of the Black Sea eddies and its dependence on characteristics of the large-scale circulation", Deep-Sea Res., no. 97, pp. 80-91.

14. Menna, M., Poulain, P.M., 2014, "Geostrophic currents and kinetic energies in the Black Sea estimated from merged drifter and satellite altimetry data”, Ocean Sci., vol. 10, no. 2, pp. 155165.

15. Shokurov, M.V., 2011, "Chislennoe modelirovanie atmosfernoy tsirkulyatsii nad Chernym morem [Numerical simulation of atmospheric circulation over the Black Sea]", Ekologicheskaya bezopasnost' pribrezhnoy i shel'fovoy zon i kompleksnoe ispol'zovanie resursov shel'fa, iss. 25, vol. 2, pp. 91-113 (in Russian).

16. Kubryakov, A.A., Shokurov, M.V., Stanichnyi, S.V. \& Anisimov, A.E., 2015, "Land-sea temperature contrasts in the Black sea region and their impact on surface wind variability", Izv. RAN. Fizika atmosfery i okeana, vol. 51, no. 4, pp. 444-453.

17. Köhl, A., 2007, "Generation and stability of a quasi-permanent vortex in the Lofoten Basin”, J. Phys. Oceanogr., vol. 37, no. 11, pp. 2637-2651. 